\title{
The Effects of Real Earnings Management on the Profitability of the Company
}

\author{
Abeer Al-Zahrani \\ Department of Accounting \\ University of Jeddah, Saudi Arabia \\ Email: gogo5002 [AT] hotmail.com
}

\begin{abstract}
This research paper was focused on investigating the effects of managing real earnings on the profitability performance of a company. The study used secondary data where co-relational research design was employed. The study used 250 companies selected from "Top 500 Companies listed on the Bombay Stock Exchange" as the sample of the study. The research findings explicitly show that managing real earnings practices adversely affect the company performance together with its corporate value. This research thus expansively contributes to the existing knowledge and literature on the relationship between managing real earnings activities and the profitability performance of a company and its corporate value.
\end{abstract}

Keywords---- Earnings, Management, Profitability, Effects

\section{INTRODUCTION}

The management of earnings has been widely investigated by various researchers in the field of accounting. The management of earnings according to Whalen (1994), happens "when the accounting managers use judgment in financial reporting as well as structuring transactions to modify the financial reports to either influence contractual outcomes that are dependent on the reported accounting numbers or mislead some stakeholders regarding the company's underlying economic performance."'The two ways of managing earnings that business managers can use to modify earnings, including "Accounting Earnings Management, and Real Earnings Management (REM)." In general, management of earnings happens when accounting managers within the company use judgmental reports in their activities as well as adjust the financial statements to misinform stakeholders on the company's overall performance which on the other hand, influences the outcomes that depend on the accounts. Earnings management interferes with the firm's general performance from stakeholders and other parties who benefit from the company, given the fact that recorded statements cannot be obscured from the organization's financial realities. This research paper, using secondary data investigated "the effects of real earnings management on the company's performance and profitability."

Gunny (2005), defined management of earnings as the "purposeful intervention in the external financial reporting process with the aim of obtaining private gain." Fraudulent accounting is not accomplished through the alteration of the firm's prevailing economic activities; however, by choice of methods of accounting to symbolise the underlying practices. On the other hand, management of real earnings is done by changing the underlying operations of the company, such as cutting prices of a firm's products and services towards the end of the year with a singular aim of accelerating sales to improve the earnings of the current financial period. Managers within a firm engage in real earnings management because of different reasons, including avoiding class action litigation that comes with aggressive accounting choices. Accordingly, the firm might have inadequate accounting elasticity, like the inability to openly report "discretionary accruals" (Barton and Simko, 2002). The management of discretionary accruals is constrained by the operations of the business as well as accrual manipulation in the prior year. Similarly, at yearend, management of accruals must be undertaken and managers are faced with indecisions regarding the type of accounting treatments will be allowed by the auditor during the prevailing financial period. In essence, the decision for business operations are managed by the manager; however, the treatments of accounting reporting must satisfy the requirements of the auditor.

Concerning the extensive presence of management of real earnings, this research investigated the effects of managing real earnings on the company's profitability and general performance. In general, the effects of managing real earnings is that it adversely affects the future performance of the company. The management of real earnings allow managers to sacrifice the firm's future profitability for the immediate financial benefits. Nonetheless, the magnitude to which various activities of managing real earnings affects the firm's future operating performances has not significantly been investigated and addressed in the currently available literature. According to the findings of this study, the four different categories of managing real earnings are associated tothe decreased future earnings after managing the performance, size, accrual levels, and industry. The results of the study thus suggest that real earnings management actions are linkedto a significant decline in the company's economic performance in the future.

A comprehensive understanding of the implication of management ofreal earnings is not only essential to the company's stakeholders but the accounting regulators also. For instance, real earnings management is one of the main 
penalties of regulations designed to restrict the managers from managing discretionary accounting earnings. According to the study by Ewert and Wagenhofer (2004), they created an analytical model which demonstrated that "real earnings management" has the capacity to increase after tightening accounting standards and making accrual management hard and challenging to undertake. Despite the current study not focusing on the "trade-off between accrual management and real earnings management, investigating the effects of real earnings management provides the needed information essential for assessing the benefits and costs of accounting standards that interact with the use of real earnings management" (Gunny, 2005).

\section{MANAGEMENT OF REAL EARNINGS CATEGORIES}

The current study focused on four categories of managing real earnings activities

i. "Decreasing discretionary Research and Development Expense"

ii. "Decreasing discretionary SG\&A Expense"

iii. "Timing the sale of fixed assets to report gains"

iv. "Overproduction and reduced prices to boost sales or reduce COGS expense" (Gunny, 2005)

\section{DISCRETIONARY SPENDING REDUCTION (R\&D AND SG\&A)}

According to the currently available rules of accounting, $R \& D$ expenditures are expense as sustained due to the ambiguity of future R\&D investment benefits. Managers interested in enhancing income in the current financial period resort to cutting R\&D investment, particularly after realization that forfeiting research and development investment would profit the company in the coming years without interfering with the present financialperiod earnings. SG\&A, on the other hand, is used in the analysis of large percentages of this expense is subjected to discretion by managers. Intangible assets like technology, brands, human capital, customer loyalty, and employee commitment are not considered as "accounting assets, all of which are created by SG\&A expenditures or advertising" (Gunny, 2005) The managers' decision to limit investment in training programs for employees designed for improving the company's human capital as well as the commitment of employees to the company, the consequences economically may not be realized immediately but in the long term.

Various research activities in the past offer extensive suggestion that company managers have a tendency working to reduce discretionary expenditure to achieve short term financial targets. Bens et al. (2002) showed how investment in R\&D and capital expenditure is reduced by managers when confronted "with earnings per share dilution because of stock option exercises" (Gunny, 2005) On the other hand, as observed by Holthausen et al. (1995),company managers do not decrease investment in R\&D, capital expenditure, or advertisement to increase bonuses for managers.

\section{"Timing the sale of fixed assets to report gains"}

The sale of asset timing is the choice of the managers and given the fact that the benefits must be included on the financial report at the time of the asset sale, the sale of asset timing can be used as a way of managing real earnings. Bartove (1993) also found out that the sale of fixed assets by managers is used to evade reportingundesirable earnings. The investigation by Harrmann, Thomas,andInoue (2003) on Japanese managers using the asset sale income to manage real earnings, found out that "companies increase (decrease) earnings by selling fixed assets and marketable securities when the current operating falls below the forecasted operating income by managers."

\section{Overproduction (reducing of prices)}

As pointed out by Roychowdhury (2003), high production is costly to the company, for a specific sales level as evidenced by manipulation of sales due to an unprecedented and abnormal discount on prices together with COGS expense manipulation because of overproduction. Price reduction "towards the end of a financial year to enhance sales from the next fiscal year into the current year, implies that the company is willing to sacrifice profits, in the long run, to register additional sales in the current financial period" (Gunny, 2005).Overproduction has the effect of losing profitability of the future after the firm re-establishes its original prices. Managers have the capacity to manipulate COGS expense at any time through overproducing in order to spread the fixed overheads over a large number of units while ensuring that per unit cost is reduced andnot balanced though holding inventory cost.

The main objective of overproducing by managers is to decrease COGS (Thomas and Zhang, 2002); nonetheless, the results might be due to poorconditionseconomically. Roychowdhury (2003) created an empirical measure for management of real earnings, discretionary expense, andoverproduction and established that managers have a tendency of trying to avoid loss reporting and thus engage in management of real earnings. Furthermore, companies that practice management of real earnings exhibit decreased operational cash flows, high costs of production, and low discretionary expense. According to Roychowdhury (2003), also observed that discount on prices offered by managers to enhance sales through myopic investment and overproduction to reduce COGS expenditures.

\section{FINANCIAL PERFORMANCE}

The firm's performance is judged subjectively based on various parameters that bring about a comprehensive understanding of effective performance. Performance management can be attributed to many factors ranging from managing issues within the company to the association of taking into consideration stakeholders as well as managing issues within the company. The survey conducted by Graham and others (2005), established that $80 \%$ of managers undertook real 
earnings management to report higher company performance. They obtained evidence that company financial managers are ready and willing to delay or limit long-term investment activities with a singular objective of increasing rates of returns, notwithstanding the potential adverse effects impacts on the company's future. In the same line, Fazeli and Rasouli(2011) also found evidence that discount price is offered by financial managers to stimulate sales at current rates and excess inventory levels to improve the revenues reported annually.

Real earnings management, as found out by Roychowdhury (2006) have an adverse impact on the value of the business in future. Using management of real earnings measures: temporary discounts and overproduction, Roychowdhury (2006) established that customers would be less inclined to buy company products in the future because of the expected price reduction. In essence, management ofreal earnings affect the company's business performance.

The agency theory is used by managers to obtain earnings intentions for their own purpose and self-interest in the short run. In this regard, financial managers tend to accept accounting suggestions together with practical actions to solve subjective expectations. Burgstahler and Eames (2006) established that operating activities cash flow is discretionarily constrained to avoid the consequences of lower reported earnings because they quickly and directly influence business results.

Hypotheses

"H1: Real earnings management adversely affect the company’s performance" (Gill et al. 2013)

"H2: Real earnings management adversely affect the company's value" (Gill et al. 2013)

\section{METHODS}

Co-relational research design was used in this study

\section{Variables}

The measures used in the analysis were:

i. Tobin's Q was used to represent the value of the firm

ii. Rate of return on assets

iii. Firm's size

iv. Financial leverage

v. Current ratio (Gill et al. 2013)

Table 1 provides an extensive definition of variables

\begin{tabular}{|c|c|}
\hline Dependent Variables & Measurement \\
\hline Return on Assets $\left(\mathrm{ROA}_{\mathrm{i}, \mathrm{t}}\right)$ & Net Income after tax/Total Assets \\
\hline Market Value $\left(\mathrm{Q}_{\mathrm{i}, \mathrm{t}}\right)$ & $\begin{array}{l}\text { "Tobin's } \mathrm{Q}=(\text { market value of equity }+ \text { book value of debt }) / \text { Book } \\
\text { value of total assets" } \\
\text { "Market value of equity }=(\text { Hieghest market value per share }+ \text { Lowest } \\
\text { market value pers share }) / 2 \text { "(Gill et al. 2013) }\end{array}$ \\
\hline Independent Variables & Measurement \\
\hline \multicolumn{2}{|l|}{ Earnings management indicator } \\
\hline $\begin{array}{l}\text { Managed Revenues }\left(\mathrm{R}_{\mathrm{i}, \mathrm{t}}\right) \\
\text { Total accruals }\left(\mathrm{TACC}-\mathrm{B}_{\mathrm{i}, \mathrm{t}}\right) \\
\text { Total Accruals(TACC- }(\mathrm{O} \mathrm{i}, \mathrm{t}) \\
\text { Discretionary Accruals }\left(\mathrm{DACC}-\mathrm{O}_{\mathrm{i}, \mathrm{t}}\right)\end{array}$ & $\begin{aligned} \boldsymbol{\Delta} & \mathrm{AR}_{\mathrm{i}, \mathrm{t}}=\mathrm{C} \times \boldsymbol{\Delta} \mathrm{R}_{\mathrm{i}, \mathrm{t}}+(1-\mathrm{C}) \times \mathbf{\Delta} \mathrm{DR}_{\mathrm{i}, \mathrm{t}} \\
\mathrm{TACC}_{-} \mathrm{B}_{\mathrm{i}, \mathrm{t}}= & \boldsymbol{\Delta} \mathrm{CA}_{\mathrm{i}, \mathrm{t}}-\boldsymbol{\Delta} \mathrm{Cash}_{\mathrm{i}, \mathrm{t}}+\boldsymbol{\Delta} \mathrm{CL}_{\mathrm{i}, \mathrm{t}}+\boldsymbol{\Delta} \mathrm{DC}_{\mathrm{i}, \mathrm{t}}-\mathrm{DEP}_{\mathrm{i}, \mathrm{t}} \\
& \mathrm{TACC} \mathrm{O}_{\mathrm{i}, \mathrm{t}} \mathrm{EARN}_{\square, \mathrm{t}}-\mathrm{CFO} \square, \mathrm{t} \\
\mathrm{DACC}_{-} \mathrm{O}_{\mathrm{i}, \mathrm{t}}= & \left(\mathrm{TACC}_{\mathrm{i}, \mathrm{t}}-\mathrm{TACC}_{\mathrm{i}, \mathrm{t}-1}\right) / \mathrm{TA}_{\mathrm{i}, \mathrm{t}}(\text { Gill et al. } 2013)\end{aligned}$ \\
\hline \multicolumn{2}{|l|}{ Control Variable } \\
\hline $\begin{array}{l}\text { Size of the firm }\left(\mathrm{FS}_{\mathrm{i}, \mathrm{t}}\right) \\
\text { Financial leverage }\left(\mathrm{FL}_{\mathrm{i}, \mathrm{t}}\right) \\
\text { Current ration - Liquidity }\left(\mathrm{C}_{\mathrm{i}, \mathrm{t}}\right)\end{array}$ & $\begin{array}{l}\text { Logarithm of total assets } \\
\text { Total debt/Total Assets } \\
\text { Current assets/Current liabilities(Gill et al. 2013) }\end{array}$ \\
\hline
\end{tabular}

Source (Gill et al. 2013)

\section{COLLECTION OF DATA}

The study utilized financial reportsfrom500 publicly traded companies between $1^{\text {st }}$ Jan. 2007 and $31^{\text {st }}$ Dec. 2011(Gill et al. 2013). The sample population was selected from "Bombay Stock Exchange Top 500 Companies" in order to come up with a random sample of companies in manufacturing. Of the 500 financial reports reported by public companies between $1^{\text {st }}$ Jan. 2007 and $31^{\text {st }}$ Dec. 2011, only 250 financial statements were usable. In this regard, the annual "cross-sectional data was used in the study." The selected 250 reports helped in the generation of 750 total observations. Given the fact that companies' selection was based on the random sampling method, the sample was "considered a representative sample" (Gill et al. 2013). The study ensured that all firms from service industry were omitted due to the fact that such companies could not provide all the information needed for the study. 


\section{RESULTS}

\section{The relationship between the management of real earnings and the performance of the firm}

Regression analysis provided the following results with regard to the effects of managing real earnings on company performance. The study utilized the Change in Managed Revenue proxy "of real earnings management intensity and firm size and financial leverage" control variables to test whether they are related to the following year's rate of return on assets.

\begin{tabular}{|l|l|l|l|l|l|l|l|}
\hline & \multicolumn{2}{|l|}{$\begin{array}{l}\text { Un-standardized } \\
\text { coefficient }\end{array}$} & $\begin{array}{l}\text { Standardized } \\
\text { coefficient }\end{array}$ & \multicolumn{1}{|l|}{ T } & Sig & \multicolumn{2}{l|}{ Collinearity Statistics } \\
\hline & B & Std. Error & Beta & & & Tolerance & VIF \\
\hline (Constant) & 0.259 & 0.036 & & 7.235 & 0.000 & & \\
$\mathrm{R}_{10}$ & -0.020 & 0.010 & -0.120 & -1.997 & 0.047 & 0.996 & 1.004 \\
\hline FS $_{10}$ & -0.033 & 0.008 & -0.270 & -4.377 & 0.000 & 0.943 & 1.060 \\
FL $_{10}$ & -0.035 & 0.009 & -0.250 & -4.043 & 0.000 & 0.940 & 1.064 \\
\hline
\end{tabular}

$\mathrm{R}_{10}, \mathrm{FS}_{10} \mathrm{FL}_{10}$, and $\mathrm{ROA}_{11}$

Source (Gill et al. 2013)

$\mathrm{R}^{2}=0.122 ;$ Adjusted $\mathrm{R}^{2}=0.111$

The change in revenues, as well as the size of the firm and financial leverage, had significant negative coefficients, thus supporting H1 (performance in 2011). The study also examined the measure of the real earnings management intensity, and results are shown below.

\begin{tabular}{|l|l|l|l|l|l|l|l|}
\hline & \multicolumn{2}{|l|}{$\begin{array}{l}\text { Un-standardized } \\
\text { coefficient }\end{array}$} & $\begin{array}{l}\text { Standardized } \\
\text { coefficient }\end{array}$ & $\mathrm{t}$ & Sig & \multicolumn{2}{l|}{ Collinearity Statistics } \\
\hline & \multicolumn{1}{|c|}{$\mathrm{B}$} & Std. Error & Beta & & & Tolerance & VIF \\
\hline (Constant) & 0.194 & 0.018 & & 10.823 & 0.000 & & \\
TACC-B & -0.035 & 0.005 & -0.566 & -6.593 & 0.000 & 0.938 & 1.066 \\
FL $_{10}$ & -0.028 & 0.006 & -0.421 & -4.904 & 0.000 & 0.938 & 1.066 \\
\hline
\end{tabular}

TACC-B $10, \mathrm{FL}_{10}$, and $\mathrm{ROA}_{11}$

$\mathrm{R}^{2}=0.379 ;$ adjusted $\mathrm{R}^{2}=0.365$

Source (Gill et al. 2013)

Table 3 shows that the link between the intensity of management of real earnings in 2010 and performance in 2011 was negative and significant. The findings also show that there is high financial leverage used by companies and was negatively related to the companies' performance in 2011.

The study also examined the association between real earnings intensity, "change in total accruals, cash flow approach (TACC-O)," and the overall performance of the company in the following year. The table below shows the results.

\begin{tabular}{|l|l|l|l|l|l|l|l|}
\hline & \multicolumn{2}{|l|}{$\begin{array}{l}\text { Un-standardized } \\
\text { coefficient }\end{array}$} & $\begin{array}{l}\text { Standardized } \\
\text { coefficient }\end{array}$ & $\mathrm{t}$ & Sig & \multicolumn{2}{l|}{ Collinearity Statistics } \\
\hline & \multicolumn{1}{|l|}{$\mathrm{B}$} & Std. Error & \multicolumn{1}{|c|}{ Beta } & & & Tolerance & VIF \\
\hline (Constant)- & 0.260 & 0.036 & & 7.249 & 0.000 & & \\
DACC-O $_{10}$ & -0.074 & 0.040 & -0.111 & -1.834 & 0.068 & 0.974 & 1.027 \\
FS $_{10}$ & -0.034 & 0.008 & -0.275 & -4.461 & 0.000 & 0.944 & 1.075 \\
FL $_{10}$ & -0.039 & 0.009 & -0.276 & -4.421 & 0.000 & 0.920 & 1.087 \\
\hline
\end{tabular}

DACC-O ${ }_{10}, \mathrm{FS}_{10}, \mathrm{FL}_{10}$, and $\mathrm{ROA}_{11}$

$\mathrm{R}^{2}=0.120$; adjusted $\mathrm{R}^{2}=0.109$

Source (Gill et al. 2013)

The results show that the management of real earnings and the performance of the firm relationship, in the following year, is negative with significance level $\mathrm{p}=-0.068$

\section{THE RELATIONSHIP BETWEEN MANAGEMENT OF REAL EARNINGS AND THE VALUE OF A FIRM}

Market perception of managing real earnings activities by corporate executives in this study was examined for 2011 and 2012. The regression of all measures of managing real earnings in 2010 on corporate value, the Tobin's Q measure was run. The study established that the relationship between the activities for managing real earnings and the firm's corporate value is positive. The management of real earnings as aforementioned is undertaken to advance the interests of the top management of the firm; it is done at the cost of other company stakeholders and thus it adversely affect the corporate value of the company. The study examined all measures of managing real earnings as an "explanatory variable" of the Tobin-Q value variation in the following year. For 2011 financial year, two of the real earnings management were significant with regressions:

i. $\mathrm{Q}_{11}=5.324-0.771\left(\mathrm{TACC}-\mathrm{B}_{10}\right)$ where $\mathrm{t}$-value of the slope coefficient 1.98, and $\mathrm{p}=0.05$ (Gill, et al. 2013)

ii. $\mathrm{Q}_{11}=6.67-0.891\left(\mathrm{TACC}-\mathrm{O}_{10}\right)$ with t-value of the slope coefficient 2.215, and $\mathrm{p}=0.028$ (Gill et al. 2013)

These results confirm the second hypothesis $(\mathrm{H} 2)$ that managing real earnings adversely affect the corporate value of the firm. 


\section{DISCUSSION}

The current study was focused on investigating whether the management of real earnings has effects of the firm's profitability. The study focused on Indian companies that practiced management of real earnings. The study established that for the Indian companies that were investigated, real earnings management in 2010 adversely impacted on their performance in the coming year. The current study findings are in tandem with (Gill et al. 2013) findings. The management of real earnings and the corporate value of a firm relationship, the study established that for Indian firms that practiced management of real earnings, their corporate value was adversely impacted.

The management ofreal earnings has the effect of shaping the business and investment decisions of a firm. For instance, in the event that real earnings management activities are directed towards achieving economic optimism, managers within the company should not suspect any future negative consequences of their decisions and management actions. However, business operations implementation originating from the subjective inclination of managers for selfinterests or personal purpose affects the performance company as well as tarnish the company's corporate value (Cohen and Zarowin 2010). The current study findings like it was showed by Cohen and Zarowin (2010), the management of real earnings have a positive influence on the performance of the company in the current financial period and negative impact in the future. Similarly, Desai and Dharmapala (2009) in their study, established that high leverage leads to matured maturities that have the effect of increasing operational costs and thus affecting the performance of the business.

\section{CONCLUSION}

The current study established that intense real earnings management practices have more significant and adverse effects on the performance of the firm while also adversely affecting the corporate value of the company in the following year. Through real earnings management, managers transfer future gains to the present with the aim of gaining from reporting good financial earnings in the present at the expense of the future. Despite the quick fixes undertaken by managers, the market detests the management ofreal earnings practices. The study established that the more intensive the management of real earnings activities, the higher the adverse effect is on the company's corporate value. In this regard, if managers have the interest of stakeholders at heart rather than their own, they must avoid managing reported corporate earnings.

\section{BIBLIOGRAPHY}

- Barton, J. and Simko, P. 2002. The balance sheetas an earnings management constraint. The Accounting Review 77: 1-27

- $\quad$ Bartov, E. 1993. The timing of asset sales and earnings manipulation. The Accounting Review. 68 (4): $840-855$.

- Bens, D., Nagar, V. and Wong, M.H.F. 2002. Real investment implications of employee stock option exercises. Journal of Accounting Research 40 (2): 359-406.

- $\quad$ Bereskin, F.L., Hsu, P.H. and Rotenberg, W., 2018. The real effects of real earnings management: Evidence from innovation. Contemporary Accounting Research, 35(1), pp.525-557.

- Burgstahler, D., Eames, M. (2006), Management of earnings and analysts forecasts to achieve zero and small positive earnings surprises. Journal of Business Finance and Accounting, 33(5-6), 633-652

- Cohen, D.A., Zarowin, P. (2010), Accrual-based and real earnings management activities around seasoned equity offerings. Journal of Accounting and Economics, 50(1), 2-19.

- Cohen, D.A., Zarowin, P. (2010), Accrual-based and real earnings management activities around seasoned equity offerings. Journal of Accounting and Economics, 50(1), 2-19.

- $\quad$ Ewert, R. and Wagenhofer, A. 2004. Economic effects of tightening accounting standards to restrict earnings management. (Working paper: Goethe-University, Frankfurt Germany and University of Graz, Austria)

- $\quad$ Ewert, R. and Wagenhofer, A., 2005. Economic effects of tightening accounting standards to restrict earnings management. The Accounting Review, 80(4), pp.1101-1124.

- Fazeli, Y.S., Rasouli, H.A. 2011. Real earnings management and the value relevance of earnings. International Research Journal of Finance and Economics, 2011, 28

- Gill, A., Biger, N., Mand, H.S. and Mathur, N., 2013. Earnings management, firm performance, and the value of Indian manufacturing firms. International Research Journal of Finance and Economics, 116, pp.13-26.

- Graham, J., C. Harvey, and S. Rajgopal. 2005. The economic implications of corporate financial reporting.Journal of Accounting and Economics40 (1-3): 3-73.

- Gunny, K.A., 2005. What are the consequences of real earnings management?.

- Gunny, K.A., 2010. The relation between earnings management using real activities manipulation and future performance: Evidence from meeting earnings benchmarks. Contemporary Accounting Research, 27(3), pp.855888.

- Herrmann, T., Inoue, T. and Thomas, W.B. 2003. The sale of assets to manage earnings in Japan. Journal of Accounting Research 41 (1) 89-108. 
- Iraya, C., Mwangi, M. and Muchoki, G.W., 2015. The effect of corporate governance practices on earnings management of companies listed at the Nairobi securities exchange. European Scientific Journal, ESJ, 11(1).

- $\quad$ Khuong, N.V., Ha, N.T.T. and Thu, P.A., 2019. The Relationship between Real Earnings Management and Firm Performance: The Case of Energy Firms in Vietnam. International Journal of Energy Economics and Policy, 9(2), pp.307-314.

- Lo, K., 2008. Earnings management and earnings quality. Journal of accounting and economics, 45(2-3), pp.350-357.

- Roychowdhury, S. 2003. Management of earnings through the manipulation of real activities that affect cash flow from operations. (Working paper, MIT)

- $\quad$ Roychowdhury, S. 2006. Earnings management through real activities manipulation. Journal of Accounting and Economics, 42(3), 335-370

- Wahlen, J. 1994. The nature of information in commercial bank loan loss disclosures. The Accounting Review 69 (July): 455-478. 